\title{
Censorship or Selection? Academic Library Holdings \\ Of the Top Ten Most Challenged Books of 2007 \\ By Rickey Best
}

\begin{abstract}
Academic libraries often serve as the protectors of challenged books. Pressure on public libraries to remove controversial works can and often does result in the restriction of access or removal of the work from those libraries shelves. Academic libraries, however, operate with a stronger sense of academic and intellectual freedom. To analyze how well academic libraries do in acquiring and making available books which appear on the American Library Association's Challenged Books list, the list for 2007 was analyzed in WorldCat to determine the number and overall percentage of academic libraries holding the titles. Overall, 29.94\% of the libraries holding challenged books were academic libraries.
\end{abstract}

\section{Introduction}

While academic libraries are generally free from the challenges of items faced by school and public librarians, issues concerning selection remain. Selection choices are generally directed by collection development policies which are aligned with institutional curricula. But do academic libraries shy away from books which might be considered controversial? Or are the intellectual freedom issues and curricular development strong enough to overcome personal hesitations to add a controversial title like Madonna's Sex? Does the inclusion of specific courses within the university curricula which deal with children's or young adult literature have an influence on the addition of titles? Perhaps the inclusion of a School of Education or Library and Information Science has an influence? Does geographic location make a difference in terms of the cultural mores impacting decisions on selecting?

\section{The Top Ten Challenged Books of 2007}

The American Library Association's top ten most challenged books for the year 2007 list was chosen since the time frame between the publication of the list and the inclusion of a library's holdings in OCLC's WorldCat was sufficient to allow for the purchase and inclusion of recently published title(s). The list, posted on the ALA website ${ }^{1}$, lists as the most challenged books the following:

1. And Tango Makes Three by Justin Richardson \& Peter Parnell. (2005)

2. The Chocolate War by Robert Cormier. (1974)

3. Olive's Ocean by Kevin Henkes. (2003)

4. The Golden Compass by Philip Pullman. (1995)

5. The Adventures of Huckleberry Finn by Mark Twain. (1884)

6. The Color Purple by Alice Walker. (1982)

7. TTYL by Lauren Myracle. (2004)

8. I Know Why the Caged Bird Sings by Maya Angelou. (1969)

9. It's Perfectly Normal by Robie Harris. (1994)

10. The Perks of Being a Wallflower by Stephen Chbosky. (1999)

Intellectual Freedom vs. Censorship The Office of Intellectual Freedom of the American Library Association annually prepares a list of the most challenged books in libraries. In examining the information from the OIF's Newsletter on Intellectual Freedom for the past three years, we see few challenges involving academic libraries. ${ }^{2}$ The majority of these challenges were for artistic and intellectual freedom, such as the inclusion of art exhibits or the intellectual 
freedom issues not related to printed works. The vast majority of challenges, however, are to be found in public and school libraries over the inclusion of specific works within the libraries collections.

Anne Scott MacLeod addresses the issues affecting censorship of children's literature in her book American Childhood: Essays on Children's Literature of the Nineteenth and Twentieth century's. MacLeod argues the debate over censorship of children's literature is based upon whether children have the same intellectual rights as adults have - is the concept of intellectual freedom applicable to children? Is that concept, in fact, even compatible with the concept of childhood?"3 MacLeod identifies two assumptions to modern views of childhood. She writes that - The first [assumption] is that children need to be separated to some degree from adult life until they have been educated or ripened in some important way. The second is that adults have something of value to teach children, so that the very concept of childhood in modern history is closely associated with that of nurture, training, and conscious education of the child by responsible adults." 4 The concepts of nurture, training, and conscious education of the child include two contradictory elements as described by MacLeod. The first is that modern middle-class childhood is managed, directed, organized and defined by adults, for the good of the child and the good of society, as adults see both. And management of childhood implies restrictions of children, usually by separating them from some aspects of society and by curtailing their access to some kinds of knowledge, experience and resources- including books.",

MacLeod traces the historical evolution of children's literature, recognizing the societal changes in the late twentieth century which argues that -children should learn as soon as possible the realities of the world they live in - even the hardest and most unsavory realities" which is balanced against those who argue for restriction based on the good of society." "This fear of the influence of children's books on the easily susceptible is the underlying element in censorship in the public and school libraries. Parents, find reasons to want books banned from libraries. The censorship for the good of society" approach is identified by Lester Asheim as a means of authoritarian control" in his essay Aot Censorship, but Selection" which appeared in the Wilson Library Bulletin in 1953, and has since been placed on the ALA Website. ${ }^{7}$

Within the academy, notes Charlene C. Cain, - thexperience of censorship by academic libraries is different from that of public and school libraries...." Cain goes on to cite the protections provided by the intellectual freedom principles of the American Library Association as well as the standards for academic freedom adopted by the American Association of University Professors. ${ }^{8}$ Decisions over selection, however, are not always easy to make. Asheim highlighted the subtle differences between selection and censorship in his essay Aot Censorship but Selection.", Asheim demonstrated three elements of censorship using George Bernard Shaw's work, Ulysses. The first where law prevented the importation of Ulysses, i.e., the work was banned by law; the second, where the librarian refuses to circulate the work; and the third instance, where a work is banned from an entire community by the extra-legal pressure of a small segment of the community." 10 As Asheim notes, -itsi the scope of the ban which distinguishes the second and third instances: the librarian controls only the content of his own 
institution; the pressure group attempts to control the content of all institutions, whether under their jurisdiction or not."11 The distinction, for Asheim lies in the approaches taken by the individuals wishing to ban a book and the librarian who wishes to select a book. The censor looks for the negative attributes of a work - its ideas, weaknesses, and possibilities for misinterpretation. The librarian, on the other hand, looks at the positive elements of a work - its values, its strengths, its virtues which will overshadow its minor faults. The positive approach of the selector asks what the reaction of a rational, intelligent adult would be to the content of a work," whereas the censor fears the results on the weak, the warped, and the irrational.", 12

Asheim addresses the distinction between censorship and selection by saying that librarians select titles in terms of -standards," but that — sme of our standards are sufficiently subjective, sufficiently vague, and sufficiently imprecise to serve the uses of the censors as well as of the selectors." 13 The standards articulated by Asheim include the intent of the author, the literary excellence of the work, and the presumed effect upon the reader. All of these standards, Asheim argues, contain a subjective element imposed by either the censor or the selector. If we have almost no evidence that books are harmful, we have less that they are not, and it is quite understandable that those who favor censorship should advocate wariness against materials which may be harmful." 14 DeVinney analyzes the history of academic freedom in regards to academic libraries and quotes from the ALA policy statement

Fenure in Libraries" that - libnaians claimed for themselves intellectual freedom, and defined it as the _freedom to develop, maintain, and improve library service...freedom in the selection of books, in the presentation of materials on all sides of controversial materials questions, and in the dissemination of information on all subjects...",15 Later revisions of the policy statement focus more specifically on procedural and policy issues to align with the standards on academic freedom and process developed by the American Association of University Professors. ${ }^{16}$

The addition of children's and young adult literature to academic library collections has been reflected in the literature by authors such as Elaine Gass Hirsch, ${ }^{17},{ }^{18}$ and Mark T. Bay. ${ }^{19}$ Hirsch noted the appeal of the literature as -encompassing college students and adults who are not studying it as part of their academic pursuits. While most students and faculty in a college's education and library science programs understand the role of children's literature in literacy development and the importance of integrating literature into the lives of children... many other clientele of academic libraries... could enjoy and benefit from it." 20 Bay noted that librarians in institutions with colleges or schools of Education are frequently charged with maintaining and developing collections of children's literature.",21

The influence of intellectual freedom has served to protect academic libraries from parents and members of the public protesting the inclusion of specific works. The basis of intellectual freedom can be found in the First Amendment to the U.S. Constitution, which reads -Congess shall make no law respecting an establishment of religion, or prohibiting the free exercise thereof; or abridging the freedom of speech, or of the press; or the right of the people peaceably to assemble, and to petition the Government for a redress of grievances.",22 However, as noted in the $5^{\text {th }}$ edition of the American Library Association's Intellectual 
Freedom Manual, -.. in academic libraries, as in all others, the greatest dangers to intellectual freedom are internal rather than external."23 These internal" dangers are primarily reflected in selection decisions.

\section{Academic Library Selection of Children and Young Adult Literature}

To examine selection patterns by academic libraries, an examination of the top ten most challenged books of 2007 was conducted. Using OCLC's WorldCat, an analysis was conducted examining library holdings of the books cited in the 2007 list within the United States. The analysis included the holdings of public and school libraries and academic libraries for institutions that offering a bachelor's degree or higher. While recognizing that not all public and school libraries include their holdings in WorldCat, the importance of the database to academic libraries allows for a reasonably accurate analysis of academic library holdings.

In looking at the list of challenged books for 2007, of note are the original publication dates of the works, which range from 1884 (The Adventures of Huckleberry Finn) to 2005 (And Tango Makes Three). The average number of years between original publication and the work appearing on the 2007 challenged books list is fifteen years. ${ }^{24}$ Because of the length of time that Huckleberry Finn has been in print, a decision was made to include only those editions which were held by a minimum of 100 libraries. For all works, the count was limited to editions in the English language only.

The 2007 Bowker Annual lists 17,046 public libraries within the United States, and 2,591 University and College Libraries. ${ }^{25}$

For the purposes of this project, World Cat records for the 2007 top ten challenged books were examined. The analysis consisted of examining the total number of libraries which had holdings for a particular record, then counting the number of academic libraries which held a copy of that specific work. For this exercise, academic libraries were defined as four-year colleges and universities, both public and private. Community and junior colleges were not included, though a number of libraries in such categories did hold copies of the works in question. To determine the proportion of holdings, an examination was conducted of the $58^{\text {th }}$ edition of American Library Directory. ${ }^{26}$ This edition of the Library Directory listed 9,734 public libraries (excluding branch libraries) in the United States, and 2,573 academic libraries at fouryear schools. The total number of all libraries within the United States, including branch libraries, medical, law, government, special, and armed forces libraries came to 30,416 . $^{27}$ Breaking this number out by region, the northeast has the most libraries $(7,662)$, followed by the Midwest $(6,747)$, the West $(3,138)$, the Southeast $(2,936)$ and the Southwest $(2,436)$ for a total of 22,919 unique libraries, excluding branches. Table 1 provides a census by region of the libraries found in the 2005-2006 edition of American Library Directory. 
Table 1

Number of Libraries by Type and Region

\begin{tabular}{|l|r|r|r|}
\hline Region & \# Public Libraries & $\begin{array}{l}\text { \# Academic } \\
\text { Libraries }\end{array}$ & \multicolumn{1}{|c|}{ Total Libraries* } \\
\hline Midwest & 3,640 & 490 & 6,747 \\
\hline Northeast & 2,809 & 549 & 7,662 \\
\hline Southeast & 1,172 & 344 & 2,936 \\
\hline Southwest & 1,151 & 194 & 2,436 \\
\hline West & 918 & 223 & 3,138 \\
\hline Total & $\mathbf{9 , 6 9 0}$ & $\mathbf{1 , 8 0 0}$ & $\mathbf{2 2 , 9 1 9}$ \\
\hline
\end{tabular}

* The total includes all libraries, including government, business, and special.

The totals for each title were listed by state. The states were then organized by geographic region, according to the geographic descriptors provided by Olsgaard and Olsgaard. ${ }^{28}$ Table 2 indicates the number of libraries and the percentages of academic libraries holding a copy of a title broken out by region. It should be noted that the table includes a column for Fotal Held by All Libraries." This total includes predominantly public and academic libraries, although some special libraries are included in these totals.

Table 2

Challenged book Holdings by Title and Region

\begin{tabular}{|l|l|r|r|r|}
\hline Book Title & Region & $\begin{array}{l}\text { Total Held by } \\
\text { all Libraries }\end{array}$ & $\begin{array}{l}\text { Academic } \\
\text { Libraries } \\
\text { Held }\end{array}$ & $\begin{array}{l}\text { \% Held by } \\
\text { Academic } \\
\text { Libraries }\end{array}$ \\
\hline $\begin{array}{l}\text { And Tango } \\
\text { Makes Three }\end{array}$ & Midwest & 242 & 6 & $2.47 \%$ \\
\hline & Northeast & 92 & 1 & $1.08 \%$ \\
\hline & Southeast & 132 & 9 & $6.81 \%$ \\
\hline & Southwest & 25 & 0 & $0.00 \%$ \\
\hline & West & 97 & 1 & $1.03 \%$ \\
\hline Total & & $\mathbf{5 8 8}$ & $\mathbf{1 7}$ & $\mathbf{2 . 8 9 \%}$ \\
\hline & & 1,051 & 271 & $18.05 \%$ \\
\hline The Chocolate & Midwest & 598 & 164 & $27.42 \%$ \\
\hline & Northeast & 539 & 169 & $31.35 \%$ \\
\hline & Southeast & 257 & 89 & $34.63 \%$ \\
\hline & Southwest & 544 & 105 & $19.30 \%$ \\
\hline & West & $\mathbf{3 , 4 3 9}$ & $\mathbf{7 9 8}$ & $\mathbf{2 3 . 2 0 \%}$ \\
\hline Total & & 1,941 & 378 & $19.47 \%$ \\
\hline & & 642 & 274 & $42.67 \%$ \\
\hline Olive's Ocean & Midwest & & & \\
\hline & Northeast & & & \\
\hline
\end{tabular}




\begin{tabular}{|c|c|c|c|c|}
\hline & Southeast & 705 & 213 & $30.21 \%$ \\
\hline & Southwest & 356 & 131 & $36.79 \%$ \\
\hline & West & 930 & 158 & $16.98 \%$ \\
\hline Total & & 4,574 & 1,154 & $25.23 \%$ \\
\hline \multirow{5}{*}{$\begin{array}{l}\text { The Golden } \\
\text { Compass }\end{array}$} & Midwest & 2,196 & 246 & $11.20 \%$ \\
\hline & Northeast & 786 & 277 & $28.88 \%$ \\
\hline & Southeast & 808 & 186 & $23.01 \%$ \\
\hline & Southwest & 376 & 111 & $29.52 \%$ \\
\hline & West & 967 & 130 & $13.44 \%$ \\
\hline Total & & 5,133 & 900 & $17.53 \%$ \\
\hline \multirow{5}{*}{$\begin{array}{l}\text { The } \\
\text { Adventures of } \\
\text { Huckleberry } \\
\text { Finn } \\
\end{array}$} & Midwest & 8,392 & 2,202 & $26.23 \%$ \\
\hline & Northeast & 5,259 & 2,215 & $42.11 \%$ \\
\hline & Southeast & 3,860 & 1,551 & $40.18 \%$ \\
\hline & Southwest & 2,256 & 998 & $44.23 \%$ \\
\hline & West & 3,141 & 1,129 & $35.94 \%$ \\
\hline Total & & 22,908 & 8,905 & $\mathbf{3 8 . 8 7 \%}$ \\
\hline \multirow{5}{*}{$\begin{array}{l}\text { The Color } \\
\text { Purple }\end{array}$} & Midwest & 3,020 & 648 & $21.45 \%$ \\
\hline & Northeast & 1,719 & 682 & $39.67 \%$ \\
\hline & Southeast & 1,805 & 562 & $31.13 \%$ \\
\hline & Southwest & 716 & 279 & $38.96 \%$ \\
\hline & West & 1,460 & 303 & $20.75 \%$ \\
\hline Total & & 8,720 & 2,474 & $28.37 \%$ \\
\hline \multirow[t]{5}{*}{ TTYL } & Midwest & 648 & 28 & $4.32 \%$ \\
\hline & Northeast & 208 & 17 & $8.17 \%$ \\
\hline & Southeast & 224 & 18 & $8.03 \%$ \\
\hline & Southwest & 98 & 11 & $11.22 \%$ \\
\hline & West & 300 & 9 & $3.00 \%$ \\
\hline Total & & 1,478 & 83 & $5.62 \%$ \\
\hline \multirow{5}{*}{$\begin{array}{l}\text { I Know Why } \\
\text { the Caged } \\
\text { Bird Sings }\end{array}$} & Midwest & 1,641 & 392 & $23.88 \%$ \\
\hline & Northeast & 941 & 414 & $43.99 \%$ \\
\hline & Southeast & 838 & 294 & $35.08 \%$ \\
\hline & Southwest & 368 & 167 & $45.38 \%$ \\
\hline & West & 670 & 175 & $26.11 \%$ \\
\hline
\end{tabular}




\begin{tabular}{|l|l|r|r|r|}
\hline Total & & $\mathbf{4 , 4 4 8}$ & $\mathbf{1 , 4 3 2}$ & $\mathbf{3 2 . 1 9 \%}$ \\
\hline $\begin{array}{l}\text { It's Perfectly } \\
\text { Normal }\end{array}$ & Midwest & 784 & 151 & $23.07 \%$ \\
\hline & Northeast & 347 & 121 & $34.87 \%$ \\
\hline & Southeast & 367 & 87 & $23.70 \%$ \\
\hline & Southwest & 188 & 57 & $30.31 \%$ \\
\hline & West & 429 & 75 & $17.48 \%$ \\
\hline Total & & $\mathbf{2 , 1 1 9}$ & $\mathbf{4 8 8}$ & $\mathbf{2 3 . 0 9 \%}$ \\
\hline $\begin{array}{l}\text { The Perks } \text { of } \\
\text { Being } a\end{array}$ & Midwest & 776 & 79 & $10.18 \%$ \\
\hline & & & & \\
\hline & & 272 & 74 & $27.20 \%$ \\
\hline & Northeast & 252 & 63 & $25.00 \%$ \\
\hline & Southeast & 157 & 35 & $22.29 \%$ \\
\hline Total & Southwest & 363 & 37 & $10.19 \%$ \\
\hline & West & $\mathbf{1 , 8 2 0}$ & $\mathbf{2 8 8}$ & $\mathbf{1 5 . 8 2 \%}$ \\
\hline $\begin{array}{l}\text { Total (All } \\
\text { Regions) }\end{array}$ & & $\mathbf{5 5 , 2 2 7}$ & $\mathbf{1 6 , 5 3 9}$ & $\mathbf{2 9 . 9 4 \%}$ \\
\hline
\end{tabular}

Analyzing the results by region, a measure was taken of the percentage of academic libraries which held the titles in question. For the top ten challenged books of 2007 , the percentage of academic libraries holding the titles are as follows: Adventures of Huckleberry Finn was first with $38.87 \%$ all of the regions reporting; I know why the Caged Bird Sings was second with 32.19\%, The Color Purple was in third place with $28.37 \%$; Olive's Ocean was in fourth place 25.23\%; The Chocolate War was fifth, with $23.20 \%$ of the copies held by academic libraries; It's Perfectly Normal was sixth, with 23.09\%; The Golden Compass was seventh, with 17.53\%; The Perks of Being a Wallflower was eighth, with $15.82 \%$ held by academic libraries; TTYL was ninth, with $5.62 \%$ held by academic libraries; finally, And Tango Makes Three was tenth, with $2.89 \%$ of the academic libraries holding a copy of the book. Overall, 29.94\% of the libraries holding copies of the challenged books for 2007 were held by four-year college and university libraries, even though these libraries comprise only $7.85 \%$ of the total population sample.

The totals of the challenged books held by academic libraries as a percentage of all libraries by region (excluding branch and departmental libraries) are shown in Table 3. In comparing holdings amongst the regions by combining all ten of the challenged titles, it appears that academic libraries in the southwest do a better job percentage wise of acquiring challenged books. In the southwest, $39.14 \%$ of the holdings in challenged books were by academic libraries, followed by $39.01 \%$ for the northeast, $33.07 \%$ for the southeast, $23.84 \%$ for the west, and $21.30 \%$ for the Midwest. The southwest, however, also has the smallest number of libraries holding a title on the 2007 challenged book list, with 4,797 libraries holding copies. This is only $8.76 \%$ of the total libraries. Conversely, the Midwest has the largest percentage of total 
libraries, with $37.72 \%$ of the total. Of the total number of academic libraries holding challenged books, the Midwest has the highest percentage of the regions with
$27.87 \%$, followed by the Northeast with $26.84 \%$, the Southeast with $19.96 \%$, the West, with $13.44 \%$, and the Southwest with $11.89 \%$.

Table 3

Challenged Books Held by Libraries By Region

\begin{tabular}{|c|r|r|r|r|r|}
\hline $\begin{array}{c}\text { Challenged } \\
\text { Books Held } \\
\text { By Region }\end{array}$ & $\begin{array}{c}\text { Total } \\
\text { Challenged } \\
\text { Books Held by } \\
\text { All Libraries }\end{array}$ & $\begin{array}{c}\text { Percentage } \\
\text { Held by } \\
\text { Libraries by } \\
\text { Region }\end{array}$ & $\begin{array}{c}\text { Total } \\
\text { Challenged } \\
\text { Books Held by } \\
\text { Academic } \\
\text { Libraries }\end{array}$ & $\begin{array}{c}\text { Total } \\
\text { Percentage } \\
\text { Books Held } \\
\text { by Academic } \\
\text { Libraries }\end{array}$ & $\begin{array}{c}\text { Percentage } \\
\text { of Books } \\
\text { Held by } \\
\text { Academic } \\
\text { Libraries } \\
\text { by Region }\end{array}$ \\
\hline Midwest & 20,655 & $37.72 \%$ & 4,401 & $21.30 \%$ & $27.87 \%$ \\
\hline Northeast & 10,864 & $19.84 \%$ & 4,239 & $39.01 \%$ & $26.84 \%$ \\
\hline Southeast & 9,530 & $17.40 \%$ & 3,152 & $33.07 \%$ & $19.96 \%$ \\
\hline Southwest & 4,797 & $8.76 \%$ & 1,878 & $39.14 \%$ & $11.89 \%$ \\
\hline West & 8,901 & $16.25 \%$ & 2,122 & $23.84 \%$ & $13.44 \%$ \\
\hline Total & $\mathbf{5 4 , 7 4 7}$ & $\mathbf{9 9 . 9 7 \%}$ & $\mathbf{1 5 , 7 9 2}$ & $\mathbf{2 8 . 8 4 \%}$ & $\mathbf{1 0 0 \%}$ \\
\hline
\end{tabular}

Curricular influences appear to play a significant role in the selection of materials by academic libraries. To determine curricular influence, a random sample of the 15,792 academic institutions was conducted. A total of 430 institutions were selected (see Appendix A for a list of the institutions examined). The websites and course catalogs of these institutions were examined to determine whether there were teacher education programs being taught at the institution and if there were courses being taught on children's literature. The course could be taught outside of the school or department of education.

The results of the survey indicated that $87.2 \%$ (375) of the colleges and universities examined had a school, college, or department of education and 12.79\% (55) did not. Additionally, the course descriptions at these institutions indicated that a course on children's or adolescent literature, reading, and/or literacy was taught at $86.28 \%$ (371) of the institutions. In the course catalog descriptions, children's or adolescent literature was specifically mentioned. Applying these percentages to the total number of academic institutions equates to 13,625 having teacher education infrastructures and coursework utilizing children's literature.

In terms of the top ten states with libraries (public, private, and special) holding copies of challenged books, the rankings are as follows:

1. New York 777

2. Illinois 641

3. Texas 568

4. Iowa 532

5. Pennsylvania 518

6. Michigan 501

7. Wisconsin 392

8. Massachusetts $\quad 370$

9. Kansas 320

10. New Jersey 310 
The top ten states with academic library holdings for challenged books are:

1. New York 140

2. Pennsylvania 121

3. California 97

4. Texas 83

5. Ohio 79

6. Illinois 74

7. Massachusetts 65

8. Michigan 62

9. Maine 62

10. Florida 62

\section{Geographic Influences}

Does geographic location have an influence on the probability of selection of challenged titles? If so, what figures influence regional selection? In considering the influence of geographic region, an examination was undertaken as to influences such as median household income and literacy / reading skills by region, using the Digest for Education Statistics, 2007. ${ }^{29}$

In examining the data, we see inconsistencies in the correlation between median household income and reading scores of children at the $8^{\text {th }}$ grade level. Table 4 provides the data broken out by region.

Table 4

Median Household Income and Reading Scores of $8^{\text {th }}$ Grade Students

\begin{tabular}{|l|r|r|}
\hline \multicolumn{1}{|c|}{ Region } & Median Household Income & $\begin{array}{c}\text { Average Reading Scores for } \\
\mathbf{8}^{\text {th }} \text { Graders in Public } \\
\text { Schools }\end{array}$ \\
\hline Midwest & $\$ 47,405$ & 266.41 \\
\hline Northeast & $\$ 53,935$ & 265.33 \\
\hline Southeast & $\$ 42,425$ & 259.66 \\
\hline Southwest & $\$ 40,229$ & 255.42 \\
\hline West & $\$ 51,214$ & 260.63 \\
\hline Average Total & $\mathbf{\$ 4 7 , 0 4 2}$ & $\mathbf{2 6 1 . 4 9}$ \\
\hline
\end{tabular}

Notably, the Midwest, with the third highest Median Household income, has the highest average reading scores. Thus, an inconsistent correlation between median income and reading scores exists. In terms of median income, regional rankings are Northeast, West, Midwest, Southeast, and Southwest, while the average reading scores are Midwest first, followed by the Northeast, West, Southeast, and Southwest. In considering the data, we recognize that the largest metropolitan areas (Boston, New York, Philadelphia, Los Angeles, San Francisco, and Seattle) with more diversified revenue streams are located primarily in the Northeast and West coast. The Midwest, with median income slightly above the average, lacks, with the exception of Chicago, major urban / industrial centers. The average reading scores, however, reflect the continuing influence of European immigrants to the region. The Swedish, Norwegian, German, and other immigrant groups influenced the region in the importance and value of education. The Southeast and Southwest, both primarily rural areas with lower median incomes, historically have been impacted by a lack of 
value assigned to education, as well as by the impact of the new wave of immigrants entering the country through Mexico.

The influence of income and reading can also be seen in the data when one examines the total number of libraries holding challenged books. For 2007, the total number of libraries holding challenged books was highest in the Midwest, followed by the Northeast, Southeast, West, and Southwest. To focus upon academic libraries and their holdings, an examination of the NCES academic library comparison database was undertaken, examining library reports on expenditures on print materials (books and serial backfiles), total library expenditures, full-time equivalent enrollment. Retrieving this data for the academic libraries included in the sample, medians were calculated by region. Table 5 provides data on academic library expenditures and median challenged book holdings per expenditure. Since there is an observed inconsistency of correlation between median income and reading scores, an analysis was undertaken of median library expenditures as reported in the NCES data for 2008. ${ }^{30}$ Table 6 shows the median book expenditures, the median total library expenditures, and the median FTE for colleges and universities by region.

Table 5

Percentage of Median Challenged Books per Academic Library Book and Total Expenditures

\begin{tabular}{|l|r|r|r|r|r|}
\hline Region & $\begin{array}{r}\text { Median Book } \\
\text { Expenditures }\end{array}$ & $\begin{array}{r}\text { Median Total } \\
\text { Library } \\
\text { Expenditures }\end{array}$ & $\begin{array}{r}\text { Median \# } \\
\text { Challenged } \\
\text { Books Held } \\
\text { Academic } \\
\text { Libraries }\end{array}$ & $\begin{array}{r}\text { \% Median } \\
\text { Challenged Books } \\
\text { / Median } \\
\text { Academic Library } \\
\text { Book Expenditures }\end{array}$ & $\begin{array}{r}\text { \% Median } \\
\text { Challenged } \\
\text { Books / Median } \\
\text { Academic } \\
\text { Library } \\
\text { Expenditures }\end{array}$ \\
\hline Midwest & $\$ 97,416$ & $\$ 874,208$ & 4,401 & 0.045 & 0.0050 \\
\hline Northeast & $\$ 155,198$ & $\$ 1,890,505$ & 4,239 & 0.027 & 0.0022 \\
\hline Southeast & $\$ 136,634$ & $\$ 1,168,533$ & 3,152 & 0.023 & 0.0026 \\
\hline Southwest & $\$ 163,467$ & $\$ 1,754,820$ & 1,878 & 0.011 & 0.0010 \\
\hline West & $\$ 300,028$ & $\$ 3,150,038$ & 2,122 & 0.007 & 0.0006 \\
\hline $\begin{array}{l}\text { Median } \\
\text { All } \\
\text { Regions }\end{array}$ & $\mathbf{\$ 1 5 5 , 1 9 8}$ & $\mathbf{\$ 1 , 7 5 4 , 8 2 0}$ & $\mathbf{3 , 1 5 2}$ & $\mathbf{0 . 0 2 0}$ & $\mathbf{0 . 0 2 0 3}$ \\
\hline
\end{tabular}

As table 5 indicates, the region with the lowest median book expenditures (Midwest) and the lowest median total library expenditures (Midwest) have the highest percentage median of challenged books based upon both median book expenditures and total library expenditures. In short, one finds challenged books are more likely to be available in the Midwest region, even though the region has a paucity of large, well-funded academic institutions compared to the northeast and western regions. This statement holds true even when looking at availability in comparison with institutional full-time equivalent enrollment, as can be seen in table 6. 
Table 6

Median Challenged Book Holdings by Academic Libraries per FTE

\begin{tabular}{|l|r|r|r|}
\hline Region & $\begin{array}{r}\text { Median } \\
\text { FTE } \\
\text { Enrollment }\end{array}$ & $\begin{array}{r}\text { Median \# Challenged } \\
\text { Books Held Academic } \\
\text { Libraries }\end{array}$ & $\begin{array}{r}\text { \% Median \# Challenged } \\
\text { Books Held by Academic } \\
\text { Libraries / FTE }\end{array}$ \\
\hline Midwest & 2,306 & 4,401 & 1.908 \\
\hline Northeast & 3,757 & 4,239 & 1.128 \\
\hline Southeast & 3,204 & 3,152 & 0.983 \\
\hline Southwest & 5,456 & 1,878 & 0.344 \\
\hline West & 7,109 & 2,122 & 0.298 \\
\hline $\begin{array}{l}\text { Median All } \\
\text { Regions }\end{array}$ & $\mathbf{3 , 7 5 8}$ & $\mathbf{3 , 1 5 2}$ & $\mathbf{0 . 8 3 8}$ \\
\hline
\end{tabular}

Table 6 shows that academic libraries in the Midwest region hold 1.908 challenged books per fte enrollment, compared to 1.128 for the Northeast, 0.983 for the Southeast, 0.344 for the Southwest, and 0.298 for the West. The Midwest, conversely, has the lowest median fte's among the regions. The Midwest, a region with the third highest median income and highest average reading scores conversely has the lowest median expenditures by academic libraries for books and the lowest total library expenditures of the five regions.

\section{Political Influences}

The issue of intellectual freedom and censorship is essentially a moral issue. Likely, then, we can make some assumptions using the red-state / blue-state determinations from the 2004 presidential election. Red sates have been identified as those who voted for President Bush, blue for those who voted for John Kerry - in other words, red is associated with the Republican Party, blue with the Democratic Party. Each party has developed regional strongholds, the Northeast and Pacific Coast for the Democrats while Republican strength is focused upon the South and Mountains/Plains. According to Norman and Merle Black, it is the Midwest that serves as the nation's swing region in national elections. ${ }^{31}$

The Republican Party has long been associated with conservative issues and, especially after the 1960s, the Democrats have been associated increasingly with liberal issues. Eonservative Republicans and liberal Democrats- as politicians, financial contributors, activists, and voters are ... the driving forces in American politics" according to the Blacks. ${ }^{32}$ The Blacks describe the liberal wing of the Democratic party as being made up of white liberals plus minorities" and assert that those identifying themselves as Hiberal" comprise 63 per cent of all Democrats. For Republicans, those who identify themselves as conservative (both white and minorities) equal 66 percent of the party. ${ }^{33}$ As Nivoli and Brady discuss, the issues of polarization can focus upon both moral and economic issues, using the antebellum debates over slavery as an example. Today issues such as abortion, women's rights, gay marriage, and school prayer have taken the forefront. For moral issues, the arguments at the party level may agree upon the right" outcome, but disagree on how to achieve that outcome. $^{34}$ 
Given these descriptions - what are the geographic implications regarding academic libraries acquiring challenged books? Using Olsgaard's regional definitions, table 5 indicates by region the number of states in the 2004 presidential election who voted Republican (conservative) or Democratic (liberal). ${ }^{35}$

Table 7

Conservative versus Liberal Voting in the 2004 Presidential Election

\begin{tabular}{|l|r|r|}
\hline Region (\# of States \& D.C.) & $\begin{array}{c}\text { 2004 Presidential Vote } \\
\text { (conservative) }\end{array}$ & $\begin{array}{c}\text { 2004 Presidential Vote } \\
\text { (liberal) }\end{array}$ \\
\hline Midwest (12) & 8 & 4 \\
\hline Northeast (12) & 0 & 0 \\
\hline Southeast (9) & 9 & 0 \\
\hline Southwest (7) & 7 & 4 \\
\hline West (11) & 7 & $\mathbf{2 0}$ \\
\hline Total & $\mathbf{3 1}$ & \\
\hline
\end{tabular}

In some instances, the data in Table 5 supports the determination by the Blacks that the Northeast is strongly supportive on liberal issues, while the Southeast (and Southwest) are strongly supportive of conservative issues. The Midwest indeed served as a -swing" region in 2004, with 8 of the 12 states voting conservatively and 4 liberally. Does the conservative / liberal label influence individuals to challenge library materials? A map prepared on Book Bans and Challenges, using data available from the American Library Association and the Kid's Right to Read Foundation indicates that for the period of 2007 to 2009, a total of 120 challenges to library materials were documented. ${ }^{36}$ Breaking these down by region, the Midwest had 36 challenges, the Southeast 29, the Northeast 22, the West 20, and the Southwest 13. By individual states, New York had the most challenges, with 9, followed by Florida with 7 and California, Illinois, Michigan, North Carolina, Oregon, Texas, and Virginia with 6 challenges each. While most challenges are never reported, it seems reasonable that the number of challenges are associated with the number of challenged books held, the cultural affinity of the region (i.e., are voters / library users -eonservative" or tiberal"), and the importance placed on reading and literacy. A difficulty in making clear connections with the Black's thesis is that the Olsgaard divisions are inconsistent with current regional definitions. As an example, Mississippi and Louisiana are included by Olsgaard in the Southwest, and mountain states such as Colorado, Montana, Utah, and Wyoming are included in the West.

\section{Conclusion}

Academic libraries provide significant support for intellectual freedom and access to challenged books. In reviewing the top ten challenged titles for 2007, eight of the challenged titles are identified in Books-InPrint on-line as being for a juvenile audience. This includes Twain's Adventures of Huckleberry Finn. In examining the lowest price listed in Books-In-Print for the titles, multiplied by the number of academic libraries holding the title, academic libraries would have spent a minimum of $\$ 64,562.80$ on acquiring the ten challenged books. While the titles easily lend themselves to degree programs in early childhood 
education, not all of the academic libraries with those titles have such programs. The acquisition of challenged books lends support not only to education, but also to sociology, political science, psychology as well as literature in general. For those institutions serving older students, the availability of the challenged books for leisure reading is an element of consideration. As noted by Strothmann and Van Fleet, - - lisure reading correlates strongly with student achievement both in the short term as well as long term success and civic participation." ${ }^{37}$ The acquisition of challenged books by academic libraries reinforces the concepts of intellectual freedom by supporting the mission of higher education to promote individual enrichment and community engagement. ${ }^{38}$

We are left asking whether approximately $30 \%$ of academic libraries holding copies of these challenged books is a good thing. Should we not be more aggressive in acquiring such titles? Do the issues of academic and intellectual freedom which resound throughout the academy call us to protect those freedoms by acquiring challenged works, particularly when public libraries are so susceptible to pressure to remove such works? Decisions by libraries to allow participate in Berman's - dity little secret" of choosing not to select whole categories or genres of materials despite public interest and the need to reflect the broad categories of human belief and activity, limits access to ideas and opinions as well as speech itself. ${ }^{39}$ We need to know more. A place to start could be by examining the curricula of educational institutions served by academic libraries holding challenged works in order to determine whether a primary focus in acquiring the works is specifically curricular, or whether broader issues pertaining to academic freedom might be in play. Additionally, we need to better understand the ties between moral and economic issues, particularly in our geographic regions, if we are to truly understand the influences leading to the acquisitions of these types of materials, as well as to potential challenges to those items. As a profession, we need to better understand the challenges that all libraries face when library materials are objected to. 


\section{Appendix A Sampled Institutions}

Abilene Christian University TX

Adams State College CO

Alabama A \& M University

Alcorn State University MS

American University DC

Amherst College MA

Angelo State University TX

Anna Maria College MA

Arcadia University PA

Arkansas State University Jonesboro

Asbury College KY

Ashland University

Assumption College MA

Auburn University Montgomery

Augsburg College MN

Augustana College IL

Augustana College SD

Austin College TX

Ave Maria University FL

Avila University

Babson College

Ball State University IN

Baptist Bible College MO

Baptist College of Florida

Barber-Scotia College NC

Barry University FL

Barton College NC

Bay Path College MA

Baylor University TX

Bellarmine University

Bellevue University

Belmont University TN

Beloit College WI

Berea College KY

Bethany College KS

Bethany Lutheran College MN

Bethel University MN

Birmingham Southern College

Blackburn College IL

Boston College MA

Boston University MA
Bradley University IL

Brescia University

Brigham Young University Hawaii

Brigham Young University UT

Bryan College TN

Buffalo State College NY

Cabrini College PA

Cal Poly Pomona

Cal State University Bakersfield

Cal State University Chico

Cal State University Fresno

Cal State University Monterey Bay

Cal State University Sacramento

Cal State University San Bernardino

Cal State University Stanislaus

Caldwell College NJ

Campbell University NC

Cardinal Stritch University WI

Carleton College MN

Castelton State College VT

Central State University OH

Charter College

Christian Brothers University TN

City College CUNY

Claremont College CA

Coe College IA

Coker College SC

Colby College ME

College of Charleston SC

College of Mount St. Vincent NY

College of St Benedict MN

College of St Rose NY

College of St Thomas More TX

College of the Atlantic ME

College of the Holy Cross MA

College of the South West NM

Columbia College MO

Columbia College SC

Converse College

Covenant College
Crichton College TN

Cumberland University TN

Dalton State College GA

Dana College NE

David N Myers College

Delaware State University

DePaul University IL

Devry University Pomona

Devry University South Florida

Dickinson College PA

Dickinson State University ND

Dillard University LA

Dixie State College UT

Dominican University IL

Donnelly College

Duke University NC

Duquense University PA

Eastern Connecticut State University

Eastern Illinois University

Eckerd College FL

Edgewood College WI

Edward Waters College FL

Elizabethtown College PA

Emmaus Bible College IA

Fairmont State College WV

Fisk University

Fitchburg State College MA

Florida Institute of Technology

Florida International University

Florida Memorial University

Florida Southern College

Fordham University NY

Fort Lewis College CO

Francis Marion University SC

Franklin W Olin College of Engineering MA

Fresno Pacific University CA

Gardner-Webb University NC

George Fox University OR

ofAdy Unum College KY

Georgia Gwinnett College GA

Goddard College VT 


\begin{tabular}{|c|c|c|}
\hline Governor's State University IL & Marylhurst University OR & Oglala Lakota College SD \\
\hline Grace College IN & Marymount University VA & Ohio Christian University \\
\hline Grand Valley State University MI & Mayville State University ND & Ohio Dominican University \\
\hline Great Basin College NV & McDaniel College MD & Ohio Valley College \\
\hline Hardin-Simmons University TX & McKendree University IL & Oklahoma Christian University \\
\hline Harris Stowe State College MO & McPherson College KS & Olivet College MI \\
\hline Haverford College PA & Medgar Evers College NY & Olivet Nazarene University IL \\
\hline Heidelberg College $\mathrm{OH}$ & Mercy College NY & Otis College of Art \& Design CA \\
\hline Henderson University AR & Miami Dade College FL & Pacific Union College CA \\
\hline Hiram College $\mathrm{OH}$ & Miami University $\mathrm{OH}$ & Paul Smiths College NY \\
\hline Hodges University FL & Midway College KY & Peace College NC \\
\hline Hood College MD & Midwestern State & Pennsylvania State University \\
\hline Hunter College NY & Mills College CA & Pepperdine University CA \\
\hline Immaculata University PA & Misericordia University PA & Polytechnic University NY \\
\hline Indiana & $\begin{array}{l}\text { Mississippi University for Wor } \\
\text { Missouri University of Science }\end{array}$ & Portland State University OR \\
\hline Indiana University Kokomo & & $\begin{array}{l}\text { ology } \\
\text { Post University CT }\end{array}$ \\
\hline Indiana University Northwest & Monroe College NY & Purdue University Calumet \\
\hline Indiana University Purdue University & limporeding State University Bozeman & Queens University of Charlotte NC \\
\hline Indiana University Southeast & Montclair State University NJ & Rice University TX \\
\hline $\begin{array}{l}\text { Iona College NY } \\
\text { Ithaca Colleoe NY }\end{array}$ & Morehead State University KY & Roanoke College VA \\
\hline $\begin{array}{l}\text { Ithaca College NY } \\
\text { Jacksonville State University }\end{array}$ & Morningside College IA & Roger Williams University RI \\
\hline $\begin{array}{l}\text { Jacksonville State University } \\
\text { Jacksonville University }\end{array}$ & Mount Holyoke College MA & Rollins College FL \\
\hline Jamestown College ND & Mount Ida College MA & Rosemont College PA \\
\hline Keene State College NH & Mount Union College $\mathrm{OH}$ & Rowan University NJ \\
\hline Kendall College IL & Mount Vernon Nazarene University OH & Rust College MS \\
\hline Kennesaw State University GA & $\begin{array}{l}\text { National Louis University IL } \\
\text { Nazareth College NY }\end{array}$ & Rutgers University NJ \\
\hline Knox College IL & $\begin{array}{l}\text { Nazareth College NY } \\
\text { New Mexico Highlands University }\end{array}$ & $\begin{array}{l}\text { Saint Ambrose University IA } \\
\text { Saint Anselm College NH }\end{array}$ \\
\hline Lake Forest College IL & New Mexico Institute of Mining \& Tec & nglogy Bant Bonaventure University NY \\
\hline Lamar University TX & New School University NY & Saint Cloud State University MN \\
\hline Lambuth University TN & New York Institute of Technology & Saint Edward's University TX \\
\hline $\begin{array}{l}\text { Lander University SC } \\
\text { Lebanon Valley College PA }\end{array}$ & $\begin{array}{l}\text { Niagara University NY } \\
\text { North Carolina A\&T State University }\end{array}$ & $\begin{array}{l}\text { Saint John's College NM } \\
\text { Saint Joseph's College ME }\end{array}$ \\
\hline Lock Haven University PA & North Carolina State University & Saint Joseph's University PA \\
\hline Long Island University CW Post & North Carolina Wesleyan College & Saint Lawrence University NY \\
\hline Long Island University Southampton & North Central College IL & Saint Mary's College CA \\
\hline Loras College IA & Northeastern University MA & Saint Mary's College IN \\
\hline Louisiana College & Northern Kentucky University & Saint Mary's University MN \\
\hline Loyola Marymount University CA & Sortbland College WI & Saint Norbert College WI \\
\hline Lynchburg College VA & Northwoed Univercity & Saint Olaf College MN \\
\hline Lyon College AR & Northwood University FL & Saint Peter's College NJ \\
\hline Manhattan College NY & Northwood University MI & Salem College NC \\
\hline Marantha College MN & Notre Dame College OH & Salisbury State University MD \\
\hline Marlboro College VT & Nyack College NY & San Diego State University \\
\hline Mary Baldwin College VA & Oberlin College OH & San Francisco State University \\
\hline
\end{tabular}




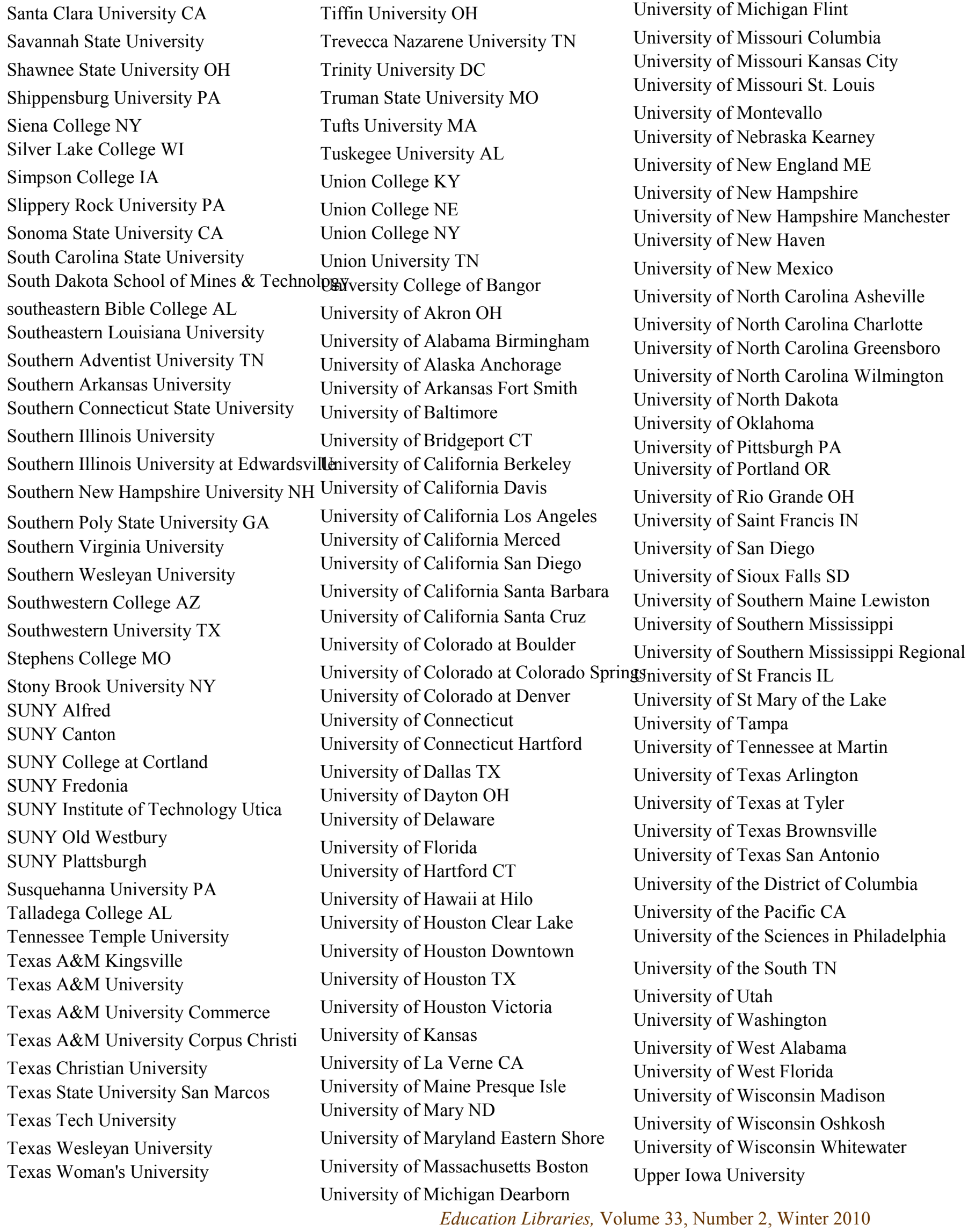




$\begin{array}{ll}\text { Valley City State University ND } & \text { Wayne State College NE } \\ \text { Vassar College NY } & \text { Wayne State University MI } \\ \text { Vincennes University IN } & \text { Waynesburg University PA } \\ \text { Virginia Commonwealth University } & \text { Weber State University UT } \\ \text { Virginia Military Institute } & \text { Wentworth Inst of Technology MA } \\ \text { Virginia Tech VA } & \text { Wesley College DE } \\ \text { Viterbo University WI } & \text { West Chester University PA } \\ \text { Walsh University OH } & \text { West Texas A\&M University } \\ \text { Wartburg College IA } & \text { Western Connecticut State University } \\ \text { Washington State University Vancouver } & \text { Western Illinois University } \\ \text { Washington University MO } & \text { Westfield State College MA } \\ \text { Wayland Baptist College TX } & \text { Westmont College CA }\end{array}$

Whitman College WA

Widener University, Delaware

Wilkes University PA

Williams Baptist College AR

Wilmington University DE

Winston-Salem State University NC

Winthrop University SC

Wisconsin Lutheran College

Woodbury University CA

Yale University CT

\section{Endnotes}

${ }^{1}$ American Library Association. Banned Books Week. What Was the Most Challenged Book of 2007? Available at: http://www.lita.org/ala/pressreleases2008/may2008/penguin.cf m. Accessed July 14, 2008,

${ }^{2}$ In September of 2006, Vol. LV, No. 5, it was reported that the library of the University of the Incarnate Word, a private Catholic university in San Antonio, Texas, was reinstating its subscription to the New York Times. The subscription had been ordered cancelled by the Dean of Library Services who objected to the Times reporting on a secret government program to monitor international banking transactions. Accessed July 13, 2008. URL: https://members.ala.org/nif/v55n5/success_stories.html\#sanant onio

${ }^{3}$ Macleod, Ann Scott. American Childhood: Essays on Children's Literature of the Nineteenth and Twentieth Centuries. Athens, GA : University of Georgia Press, 1994. p. 174

${ }^{4}$ Ibid, p. 176.

${ }^{5}$ Ibid, p. 176-177.

${ }^{6}$ Ibid, p. 185 ,

${ }^{7}$ Asheim, Lester. Not Censorship but Selection." Wilson Library Bulletin 28 (September 1953) p. 6. Available at: http://www.ala.org/ala/oif/basics/notcensorship.cfm. Accessed June $30^{\text {th }}, 2008$.

${ }^{8}$ Cain, Charlene C. Intellectual Freedom in Academic Libraries." Louisiana Libraries 68(3) 2006; p. 29.

${ }^{9}$ Asheim, Lester. Not Censorship but Selection." Wilson Library Bulletin 28 (September 1953) p. 6. Available at: http://www.ala.org/ala/oif/basics/notcensorship.cfm. Accessed June $30^{\text {th }}, 2008$.

${ }^{10}$ Ibid; Available at: http://www.ala.org/ala/oif/basics/notcensorship.cfm. Accessed June $30^{\mathrm{th}}, 2008$.

${ }^{11}$ Ibid; Available at: http://www.ala.org/ala/oif/basics/notcensorship.cfm. Accessed June 30th, 2008.

${ }^{12}$ Ibid; Available at: http://www.ala.org/ala/oif/basics/notcensorship.cfm. Accessed June $30^{\text {th }}, 2008$.

${ }^{13}$ Asheim, Lester. Not Censorship but Selection." Wilson Library Bulletin 28 (September 1953) p. 6. Available at: http://www.ala.org/ala/oif/basics/notcensorship.cfm. Accessed June $30^{\mathrm{th}}, 2008$.

${ }^{14}$ Ibid; Available at: http://www.ala.org/ala/oif/basics/notcensorship.cfm. Accessed June $30^{\text {th }}, 2008$.

${ }^{15}$ DeVinney, Gemma. - Aademic Librarians and Academic Freedom in the United States." Libri 36 (March 1986) p. 30; and Tenure in Libraries" ALA Bulletin 40 (November 1946) ;. 451 (see reference 39).

${ }^{16}$ See - AGuideline for the Appointment, Promotion, and Tenure of Academic Librarians: Approved at ALA Annual Conference, June 2005." College \& Research Libraries News 66 (9) 2005; pp. 668-676.

${ }^{17}$ Hirsch, Elaine Gass. You have kids‘ books?!” Promoting children"s literature in an academic library." Education Libraries: Children's Resources, 31(3) Spring, 2008; pp. 1316.

Education Libraries, Volume 33, Number 2, Winter 2010 
${ }^{18}$ Hirsch, Elaine Gass. - $-n$ becoming a Children's Literature Librarian in an Academic Library." OLA Quarterly 12(2) 2006; pp. 2-3.

${ }^{19}$ Bay, Mark T. Selecting Children's Literature for Academic Librarians: Tips from the Trenches." Behavioral \& Social Sciences Librarian 19(2) 2001; pp. 1-6.

${ }^{20}$ Hirsch, Elaine Gass. You have kids‘ books?!” Promoting children's literature in an academic library." Education Libraries: Children's Resources, 31(3) Spring, 2008; p 13.

${ }^{21}$ Bay, Mark T. Selecting Children's Literature for Academic Librarians: Tips from the Trenches.” Behavioral \& Social Sciences Librarian 19(2) 2001; p. 2.

${ }^{22}$ Vile, John R. Encyclopedia of Constitutional Amendments, Proposed Amendments, and Amending Issues, 1789-2002. $2^{\text {nd }}$ edition. Santa Barbara, CA: ABC-CLIO, 2003. pp. 532-533.

${ }^{23}$ American Library Association. Office of Intellectual Freedom. Intellectual Freedom Manual $5^{\text {th }}$ edition. Chicago : American Library Association, 1996; p. 283.

${ }^{24}$ Original publication dates for the titles are: The Adventures of Huckleberry Finn (1884); And Tango Makes Three (2005); The Chocolate War (1985); The Color Purple (1982); The Golden Compass (1995); I Know Why The Caged Bird Sings (1969); It's Perfectly Normal (1994); Olive's Ocean (2003); The Perks of Being a Wallflower (1999); and TTYL (2004);

${ }^{25}$ Number of Libraries in the United States and Canada" The Bowker Annual 2007 52nd Edition. Medford, NJ:

Information Today, Inc., 2007. p. 407.

${ }^{26}$ American Library Directory $58^{\text {th }}$ edition, 2005-2006.

Medford, NJ: Information Today, 2005; v. 1, p. xii.

${ }^{27}$ American Library Directory $58^{\text {th }}$ edition, 2005-2006. Medford, NJ: Information Today, 2005; v. 1, pp. xii-xiii.

${ }^{28}$ Olsgaard, John N. and Olsgaard, Jane Kinch. -Athorship in Five Library Periodicals." College \& Research Libraries 41(1) (1980); p. 50.

${ }^{29}$ Department of Education. Institute of Education Sciences. Digest of Education Statistics, 2007. Available at: http://nces.ed.gov/pubsearch/pubsinfo.asp?pubid=2008022. Accessed December $18^{\text {th }}, 2009$.

Public Library Funding data from IMLS http://harvester.census.gov/imls/compare/PeerVariableNumeri c.asp
${ }^{30}$ United States Department of Education. National Center for Education Statistics. Compare Academic Libraries (2008 data). Available at:

http://nces.ed.gov/surveys/libraries/compare/index.asp?Librar yType $=$ Academic

${ }^{31}$ Black, Norman and Black, Merele. Divided America: the Ferocious Power Struggle in American Politics. New York : Simon \& Schuster, 2007; pp. 1.

${ }^{32}$ Ibid; p. 2.

${ }^{33}$ Ibid; p. 3 .

${ }^{34}$ Nivola, Pietro S. and Brady, David W. Red and Blue Nation? : Consequences and Correction of America's Polarized Politics. Stanford University : Hoover Institution on War, Revolution \& Peace, 2008; pp. 127-148.

${ }^{35}$ Gastner, M. T.; Shalizi, C.R., and Newman, Michael J. Maps and Cartograms of the 2004 Presidential Election." University of Michigan, 2004. Website available at: http://www-personal.umich.edu/ mejn/election/2004/. Accessed January $6^{\text {th }}, 2010$.

${ }^{36}$ Google Maps. Book Bans and Challenges, 2007-2009. Available at:

http://maps.google.com/maps/ms?ie=UTF8\&hl=en\&oe=UTF8 $\underline{\text { \&source }=\text { embed } \& \mathrm{t}=\mathrm{h} \& \mathrm{msa}=0 \& \mathrm{msid}=1123176173036797246}$ $08.00047051 \mathrm{ed} 493 \mathrm{efec} 0 \mathrm{bb} 8 \& 1 \mathrm{l}=38.68551,-$ $96.503906 \& \mathrm{spn}=32.757579,56.25 \& z=4$. Accessed January $7^{\text {th }}, 2010$.

${ }^{37}$ Strothmann, Molly and Van Fleet, Connie. Books that Inspire, Books that Offend." Reference \& User Services Quarterly 49(2) (2009) p. 165.

${ }^{38}$ Ibid, p. 165.

${ }^{39}$ Berman, Sanford. Inside Censorship." Progressive Librarian 18 (2001); p. 49.

Rickey Best, Collection Development Librarian Auburn University at Montgomery Library rbest@aum.edu 